\title{
IN VITRO RESPONSE GROWTH OF STEVIA REBAUDIANA UNDER SALINITY AND DROUGHT
}

\author{
Mubarak, M. ${ }^{1}$, A. H. Belal ${ }^{1}$, E. I. EI $\operatorname{Sarag}^{1}$, and M. N. EL-Din ${ }^{2}$ \\ 1. Dept. of Plant Prod., Faculty Environ. Agri. Sc., El-Arish, Suez Canal Univ., Egypt \\ 2. Res. Ins. of Agric. Genetic Engin., AGERI, ARC., Egypt. \\ "Corresponding: mobark mohamed99@yahoo.com
}

\begin{abstract}
This work aimed to evaluate growth of Stevia rebaudiana under stress conditions. The plantlets were cultured on modified MS medium supplemented with different concentrations of $\mathrm{NaCl}$ at 0.0, 5000, 7500 and $10000 \mathrm{ppm}$ for salinity stress, as well as mannitol at 0.0, 5, 7.5 and 10 bar. Results showed that the plantlet growth characters decreased as salinity and drought stress level increased, Plantlet growth traits significantly varied under deferent stress levels. Drought strees was more sever on plantlet growth than salinity stress. The highest values for plantlet growth traits were observed at $5000 \mathrm{ppm}$ salinity level while the lowest values were observed at 10 bar drought stress. Some treatments were promised stevia tolerance under both of salinity and drought stress conditions.
\end{abstract}

Key words: Stevia rebaudiana, micropropagation, drought, salinity and stress.

\section{INTRODUCTION}

Stevia rebaudiana Bertoni is a small shrub of the Asteraceae (Composite) family, Stevia is an herb with an extensive root system and brittle stems producing small, elliptic leaves, the tiny white florets are perfect, borne in small corymbs of 2-6 florets. Corymbs are arranged in loose panicles.

Oddone (1997) considered that stevia is self-incompatible and insect pollinated. Additionally, he mentioned that clear seeds are infertile. Seeds are contained in slender achene's, about $3 \mathrm{~mm}$ in length. Each achene has about 20 persistent pappus bristles. The native occurrence of Stevia rebaudiana is between $22-24^{\circ} \mathrm{S}$ and $53-56^{\circ} \mathrm{W}$ in Paraguay and Brazil. The plant growth requires mild temperature between $15^{\circ}$ and $38^{\circ} \mathrm{C}$ and relative humidity of about $80 \%$ (Soejarto et al., 1983). The cultivation of such a plant could be an alternative for the new land reclamation projects to meet the sugar demands of the Egyptian markets and generate income for the growers.

(El-Zifzafi, 2003 and Ibrahim et al., 2008).Stevia is helpful for hypoglycemia and diabetes because it nourishes pancreas and thereby helps to restore its normal function (Soejarto et al., 1983). Oviedo (1971) reported that $35.2 \%$ fall in normal blood sugar levels whiten 6-8 hours following to the ingestion of stevia leaf extract (Miyazaki et al., 1978). Also, Stevia leaves extract can be used as anti fungal and anti bacteria agent. Therefore, it lowers incidence of cold and flu. Poor seed germination is one of the factors limiting large scale cultivation. 
In this concern, referred to Shock (1982); Duke (1993) and Carneiro et al. (1997) who reported that poor viable seeds were produced by stevia with very low germination percentage (Felippe and Lucas, 1971; Latha and Usha, 2003). Seed germination rate is often poor, less than $10 \%$ are common (Miyazaki et al., 1978; Goettemoeller and Ching, 1999).

Stevia grows well in sandy loam soils with an ample supply of water. Stevia prefers acidic to neutral soil with a $\mathrm{pH}$ range of 6.5-7.5 for its best growth. Saline soils should be avoided as stevia plant is susceptible to water logged conditions. Stevia rebaudiana is best grown in sunny areas of the garden or in containers. Raised beds are the best choice for growing this herb if the soil is heavy or has high clay content. Ideal soil would be a friable garden loam high in organic matter. Soil $\mathrm{pH}$ levels range from acid to slightly alkaline.

Stevia is not a drought tolerant herb; the soil should be kept continuously moist, but not saturated (Tucker and Thomas, 2009). Goettemoeller (2010) and the Herb Society of America (2010). The present investigation aimed to evaluate Stevia rebaudiana for optimum propagation via tissue culture techniques both under drought and saintly stress conditions.

\section{MATERIALS AND METHODS}

This study was carried out in Plant Tissue Culture Laboratory, Faculty of Environmental Agricultural Sciences (FEAS) El-Arish, North Sinai, Suez Canal University (SCU). The present work was conducted to display in details the whole protocol for stevia propagation through tissue culture techniques to produce and introduce Stevia rebaudiana plants as a new sweetener crop to Egyptian agriculture.

In order to efficiently maximizing of plant propagation via direct organogenesis, it is important to study the influence of stress factors on the growth and development of Stevia rebaudiana grown in vitro. Seedlings of Stevia rebaudiana var. Spanti were kindly obtained from Sugar Crops Res. Inst., Agri., Res. Cent., Ministry of Agri., Egypt, which were grown in the greenhouse of the Faculty of Environ. Agri. Sc. El-Arish. Actively growing shoots were used as the explants source during period from February to March. The terminal shoots were collected from growing plants which were 2-3 months age and were cut into $1-1.5 \mathrm{~cm}$ pieces.

\section{Expellant sterilization.}

Shoot tip explants of stevia ranging in size from 0.5 to $1 \mathrm{~cm}$ were rinsed under running tap water with soap for 5 minutes to remove all the remaining detergent, then washed with sterilized distilled water. The explants were soaked for 10 minutes in $20 \%$ clorox concentration for explants surface sterilization, followed by $1.5 \mathrm{gl}^{-1}\left(\mathrm{HgCl}_{2}\right)$ Mercuric chloride for one minute, then washed with sterilized distilled water for 3-4 times to remove all traces.

All steps of the sterilization had been done under aseptic conditions inside the culture cabinet (Laminar air flow hood) when ten explants were cultured in each jar to containing $50 \mathrm{ml}$ medium.Medium for all cultures contained $1.1 \mathrm{gl}^{-1} \mathrm{MS}$ (Murashige and Skoog, 1962) inorganic salts supplemented with $0.1 \mathrm{gl}^{-1}$ myoinositol, $30.0 \mathrm{gl}^{-1}$ sucrose and $6.0 \mathrm{gl}^{-1}$ Agar.

The $\mathrm{pH}$ of the medium was adjusted to 5.7 and autoclaved at $1.2 \mathrm{kgcm}-2$ and 121 ${ }^{\circ} \mathrm{C}$ for 20 minutes. For salinity experiment MS medium was supplemented with different concentration of $\mathrm{NaCl} 0,5000$, 7500 and $10000 \mathrm{ppm}$. While, for drought experiment, MS Medium was supplemented with different concentrations of mannitol 0 , 5, 7.5 and 10 bar. The amounts of mannitol needed to produce these osmotic potentials were $0, \quad 37.31, \quad 55.83$ and $74.34 \mathrm{gl}^{-1}$ $(W / V)$. The concentrations of mannitol were 
calculated according to formula given by Helmerick and Pferifer (1954).

$(\mathrm{P}=\mathrm{g} \mathrm{R} \mathrm{T} / \mathrm{mV})$.

Where:-

$\mathrm{P}=$ osmotic potential in atmosphere

$\mathrm{g}=$ grams of mannitol

$\mathrm{R}=0.0825$ liter atmospheres per degree per mole

$\mathrm{T}=$ absolute temperature

$\mathrm{m}=$ molecular weight of mannitol

$\mathrm{V}=$ volume in liters.

The jars for each experiment (salinity and drought stress) were incubated at $25 \mathrm{C}$ under 16/8 light/dark photoperiod regime with intensity about 3000 lux.

\section{Statistical analysis:}

Data were statistically analyzed by using a randomized complete design (RCD). Mean separations were done by using SPSS computer program and to compare between means least significant differences (Duncan, 1955) was used. Data were recorded every six weeks every treatment had four replicates.

\section{RESULTS AND DISCUSSION}

At multiplication stage, treatments included different concentrations of $\mathrm{Na} \mathrm{Cl}$ and mannitol to study their effect on some vegetative characteristics. Data in Table (1) shows the effect of salinity and drought caused by $\mathrm{NaCl}$ and mannitol, respectively on stevia growth after six weeks of treatments. Control treatment was the best for all traits.

\section{Shoot number and length:}

The highest shoot number under stress was 16 with 5000 ppm salinity stress, while the smallest shoot number value was (9.6) with 10000 ppm salinity stress, Generally the number of shoots were significantly decreased $(16,11$ and 9.6$)$ as the salinity levels increased $(5000,7500$ and10000 ppm, respectively).
While the shoot length was 1.9, 1.8 and 1.6 under the same stress levels, respectively and there were no significantly differences between both 5000 and 7500 ppm concentrations.

Concerning the shoot number and length, the control treatment gave the greatest values (56 and 5.46, respectively). On the other hand, the shoot number values under drought stress decreased(8,4, 7.0 3.4) as the drought level increased, they ranged between 8.4 and 3.4 shoots with 5 and 10 bar treatments, respectively. While the shoot length values were $0.82,0.54$ and $0.38 \mathrm{~cm}$ with $5,7.5$ and 10 bar mannitol levels, respectively.

\section{Node and leaf number:}

For both node and leaf number traits, the values of these traits decreased as the stress type levels increased and there were slight differences between stress treatments. It seems that both salinity and drought stress gave the same effect on both treats. The highest values were 2.2 and 4.2 for both traits (node and leaf number) with5000 ppm salinity stress, while they were 2.2 and 4.4 with 5 bar of drought stress.

\section{Root number and root length.}

For root number of stevia, all tested treatments showed similar trend. The least value of root length were recorded with 5bar treatment while the highest value was observed with other treatments. There were no roots observed in both 7.5 and 10 bar drought stress treatments, while the highest root number value 15.2 was obtained roots with 5000 ppm salinity stress.

The highest root length value $29 \mathrm{~cm}$ was obtained with 5000 ppm salinity stress. The highest survival rate percentage value was $92 \%$ was observed with $5000 \mathrm{ppm}$ salinity stress, while the smallest survival rate percentage value was $22 \%$ with 10 bar drought stress. 
Table (1): Effect of different concentrations of $\mathrm{NaCl}$ and mannitol stress on growth characters of cultured Stevia rebaudiana after six weeks of treatments.

\begin{tabular}{cccccccc}
\hline Treatments & $\begin{array}{c}\text { Shoots } \\
\text { number }\end{array}$ & $\begin{array}{c}\text { Shoot } \\
\text { length } \\
(\mathbf{c m})\end{array}$ & $\begin{array}{c}\text { Nodes } \\
\text { number }\end{array}$ & $\begin{array}{c}\text { leaves } \\
\text { number }\end{array}$ & $\begin{array}{c}\text { Roots } \\
\text { number }\end{array}$ & $\begin{array}{c}\text { Roots } \\
\text { Length } \\
(\mathbf{c m})\end{array}$ & $\begin{array}{c}\text { Survival } \\
\text { rate \% }\end{array}$ \\
\hline $\begin{array}{c}\text { Control } \\
\mathbf{5 0 0 0} \mathbf{~ p p m}\end{array}$ & $56^{\mathrm{a}}$ & $5.46^{\mathrm{a}}$ & $4.4^{\mathrm{a}}$ & $8.8^{\mathrm{a}}$ & $45.8^{\mathrm{a}}$ & $110^{\mathrm{a}}$ & $100^{\mathrm{a}}$ \\
$\mathbf{N a C l}$ & $16^{\mathrm{b}}$ & $1.9^{\mathrm{b}}$ & $2.2^{\mathrm{b}}$ & $4.2^{\mathrm{bc}}$ & $15.2^{\mathrm{b}}$ & $29^{\mathrm{b}}$ & $92^{\mathrm{b}}$ \\
$\begin{array}{c}\mathbf{7 5 0 0} \mathbf{~ p p m} \\
\mathbf{N a C l}\end{array}$ & $11^{\mathrm{c}}$ & $1.8^{\mathrm{b}}$ & $1.6^{\mathrm{bc}}$ & $3.2^{\mathrm{c}}$ & $12.2^{\mathrm{c}}$ & $23^{\mathrm{c}}$ & $78^{\mathrm{c}}$ \\
$\begin{array}{c}\mathbf{1 0 0 0 0} \mathbf{~ p p m} \\
\mathbf{N a C l}\end{array}$ & $9.6^{\mathrm{c}}$ & $1.6^{\mathrm{c}}$ & $2^{\mathrm{b}}$ & $4.6^{\mathrm{b}}$ & $4.8^{\mathrm{d}}$ & $8.6^{\mathrm{d}}$ & $68^{\mathrm{d}}$ \\
$\begin{array}{c}\mathbf{5} \mathbf{b a r} \\
\mathbf{m a n n i t o l}\end{array}$ & $8.4^{\mathrm{cd}}$ & $0.82^{\mathrm{d}}$ & $2.2^{\mathrm{b}}$ & $4.4^{\mathrm{b}}$ & $4.6^{\mathrm{d}}$ & $6.2^{\mathrm{d}}$ & $56^{\mathrm{e}}$ \\
$\begin{array}{c}\mathbf{7 . 5} \mathbf{b a r} \\
\text { mannitol } \\
\mathbf{1 0} \mathbf{b a r}\end{array}$ & $7^{\mathrm{d}}$ & $0.54^{\mathrm{de}}$ & $2^{\mathrm{b}}$ & $4^{\mathrm{bc}}$ & 0.00 & 0.00 & $42^{\mathrm{f}}$ \\
$\mathbf{m a n n i t o l}$ & $3.4^{\mathrm{e}}$ & $0.38^{\mathrm{e}}$ & $2^{\mathrm{b}}$ & $4^{\mathrm{bc}}$ & 0.00 & 0.00 & $22^{\mathrm{g}}$ \\
\hline
\end{tabular}

\section{Survival rate:}

Using $\mathrm{NaCl}$ induced a bad effects on all parameters under study up to the lethal concentration which caused by 5000 ppm $\mathrm{NaCl}$ under Salinity stress which caused almost death of the in vitro plantlets.

Increasing mannitol concentration in the medium, resulted in a significant for vegetative characters. Salt or mannitol tolerant cell lines selected by this way had smaller cells than unselected cell lines when cultured in the presence of salt or mannitol.

Cell lines selected for tolerance to one agent (sodium salt, potassium salt or mannitol) showed minimal tolerance to another agent. However, when plants were regenerated from salt- or mannitoltolerant callus and new cultures derived from them, the new cultures showed tolerance to all of the salts and mannitol experiments.
Plant regeneration from the new cultures was not achieved under the conditions that led to the regeneration of the parent plants from callus. Plant cells contain large vessels known as vacuoles. These structures serve a number of functions, including water storage. Wellhydrated vacuoles push against the thick cell walls making the cell rigid, or turgid. When all cells are turgid, the plant itself is firm and crisp. When a plant loses water, the vacuole contracts and cannot maintain this pressure.

The cells become flaccid and the plant wilts.(Epstein et al., 1980, Francois et al., 1986, Sharp et al., 1990). When water is scarce, aging foliage becomes a liability to the plant.

Deciduous plants may undergo early senescence, in which leaves go through the natural shedding process ahead of schedule. Other plants may simply shed wilted leaves. Symptoms of drought- 
induced defoliation include curling, rolling, folding and eventual shedding of the leaves.(Munns and Termaat, 1986; Munns, 1993; Beltras et al., 1997). These results are in agreement with those obtained by (Ochatt and Power 1989); Zidan et al., 1990; Hussain and Rahman, 1995; Andria et al., 1997; Tedeshi et al., 1997; Escobar et al. (1998); Ledbetter et al (1998); ELMidaoui et al., 1999; Abdel-Sadek, 2003; El-Zifzafi, 2003; Hossain et al., 2008; Pratibha et al. 2010) they found that plant response to salt stress varies at different developmental stages.

Increasing salinity during plant development would delay germination, vegetate growth reduction and formation of thinner roots. Stalinization can inhibit both cell division and cell expansion in growing tissues of roots, stems and leaves.

\section{REFERENCES}

A. D. Kinghorn (1983). Potential sweetening agents of plant origin. Economic Botany, 37(1): 71-79.

Abdel-Sadek, H. B. (2003). Identification of fingerprints and marker-assisted selection for stress tolerance in some accessions of Stevia rebaudiana. M.Sc. Thesis, Genetics Dep., Fac. Agric., Ain Shams Univ.

Beltras, J, D. trindade, P. J. Correia and K.S. Chartzoulakis (1997). Lettuce yield esponse to salinity of sprinkle irrigation of horticulture. Horticulture, 449, 623-627.

Duke, J. (1993). Stevia rebaudiana In: handbook of "Alternative Cash Crops", CRC Press, Boca Raton, 422424.

Duncan, B. D. (1955). Multiple range and multiple F-test. Biometrics. 11:1- 42.

EL-Midaoui, M., A. Talouzte, M. Benbella, H. Serieys, A. Berville and M. Tersac (1999). Response of five sunflower genotypes to different concentrations of sodium chloride proceeding of the Fourth European Conference of Sunflower Biotechnology. France. 20-23 Oct. 1998. Hellia, 22:30, pp 125-138.

Epstein, E.; J.D. Norlyn, D. W. Kingsobury, D. B. Kelley, G. A. Cunniningham and A. F. Wrona (1980). Salline culture crops and genetic approach. Science, 210: 399404.

Escobar-G.A.J; B. Zipperlin; F. Carbonne; A. Moing and J.P. Gaudillere (1998). Photosynthesis, carbon partitioning and metabolite content during drought stress in peach seedlings Australian-Journal- ofPlant- Physiology; 25(2): 197-205.

Felippe, G. M. and N. M. C. Lucas (1971). Estudo daviabilidade dos frutos de Stevia rebaudiana Bert. Hoehnea, 1: 95-105.In: in vitro cellular and Developmental: Biology Plant. 39 (5): 523.

Francois L.E., E.V. Mass, J. Donovan and V. L. Young (1986). Effect of salinity on grain yield and quality, vegetive growth and germination of sime-dourf and durum wheat. Agron. J., 78: 1053-1058.

Goettemoeller, J. and A. Ching (1999). Seed germination in Stevia rebaudiana. Perspectives on new crops and new uses. J. tanick (ed.), ASHS press. Alexandria. V A 510511.

Goettemoeller, J. (2010). Growing Stevia for the Market: Farm, Garden, and Nursery Cultivation of the Sweet Herb,Stevia rebaudiana. Maryville, Missouri: Prairie Oak Publishing, 2010.

Helmerick, R.H. and R.P. Pferifer (1954). Differential varietial responses of winter wheat germination and early growth to controlled limited moisture levels. Agron.J.46: 560-562. 
Hossain, M. A.; A. H. M. Shamim; T. A. Jahan and M. N. Hasan (2008). Micro propagation of stevia. Int. J. Sustain. Crop Prod. 3(4):1-9.

Hussain, M. K. and O.V. Rahman (1995). Breeding sunflower for salt tolerance: association of seeding growth and mature plant traits for salt tolerance in cultivated sunflower. Hellia, 18, 22: 69-76.

Ibrahim. I. A.; M. I. Nasr; B. R. Mohammed and M. M. EL-Zifzafi (2008). Plant growth regulators affecting in vitro cultivation of Stevia rebaudiana. Sugar Tech. 3 (10):248253.

Kinghorn, D. A. (2002). Stevia: The Genus Stevia. New York: Taylor and Francis, Inc.

Latha, S. and M. Usha (2003). In vitro culture studies on Stevia rebaudiana. InVitro Cellular and Developmental Biology Plant. 39(5): 520-523.

Ledbetter, C. A; D. E. Palmquist. and S. J. Peterson (1998). Germination and net in vitro growth of peach, almond and peach-almond hybrid embryos in response to mannitol inclusion in the nutrient medium, Euphytica-; 103(2): 243-250.

Margara, J. and M. T. Piollat (1985). Evolution de 1, aptitude al, orango gene se in vitro a partir de Saintpaulia ionanthaau corus descultures successives, CrA cad Sc Paris 301:265-268.

Miyazaki, Y.; H. Watanabe and T. Watanabe (1978). Studies on the cultivation of Stevia rebaudiana Bertoni. Yield and stevioside content of 2-year-old plants. Eisi Shikenjo hokoku., 96: 86-89.

Munns, R. (1993). Physiological process limiting plant growth on saline soils some dogmas and hypotheses. Plant Cell Environmental, 16: 15-24.
Munns, R. and Termaat, A. (1986): Whole plant responses to salinity. Aust. J. Plant Physi., 13: 143-160.

Murashige, T. and F. Skoog (1962). A revised medium for rapid growth and bioassays with tobacco tissue cultures. Physiol., Plant, 15: 473-497.

Ochatt,-S-J and J.B Power (1989). Selection for salt and drought tolerance in protoplast- and explantsderived tissue cultures of Colt cherry (Prunus avium $X$ pseudocerasus) Tree-Physiology; 5(2): 259-266.

Oddone, B. (1997). How to grow stevia. Technical manual. Guarani Botanicals, Pawtucket, CT.

http://www.scribd.com/doc/6390515/Ad vances-in-Agronomy-Volume-89.

Oviedo, C.A. (1971): Accion hipoglicemiante de la Stevia rebaudiana Bertoni (Kaa-he-e). Excerpta Medica. 208:92-93.

Pratibha. G, Satyawati. S. and Sanjay S. (2010). Callusing in Stevia rebaudiana (NaturalSweetener) for Steviol Glycoside Production. Int. J. of Agric. and Bio. Sci. 1:1.

Sharp, R. E., T. C. Hsiao and W. Kuhunsilk (1990). Growth of the maize primary root at low water potentials. Plant physic., 93, 13371346.

Soejarto, D. D.; C.M Compadre; P.J Medon; S.K. Kamath and Tedeshi, P., R. Andria, P. Giorio, G. Sorrentino, G. Romano and A. Handy (1997). Grain yield, oil, leaf water status and photosynthesis as affected by saline irrigation water in a field grown sunflower crop. Valenzona, Bari, Italy, 22-26. Sep. 69-82. (En. Abst).

The Herb Society of America (2010). Visit www.herbsociety.org for information on joining The Herb Society of America 9019 Kirtland 
SINAI Journal of Applied Sciences (ISSN: 2314-6079) Vol. (1), Is.:(1), Dec. 2012.

Chardon Rd. Kirtland, Ohio 44094 440.256.0514,

herbs@herbsociety.org.

Tucker, A. O., and Thomas DeBaggio

(2009). The Encyclopedia of Herbs:

A comprehensive Reference to Herbs
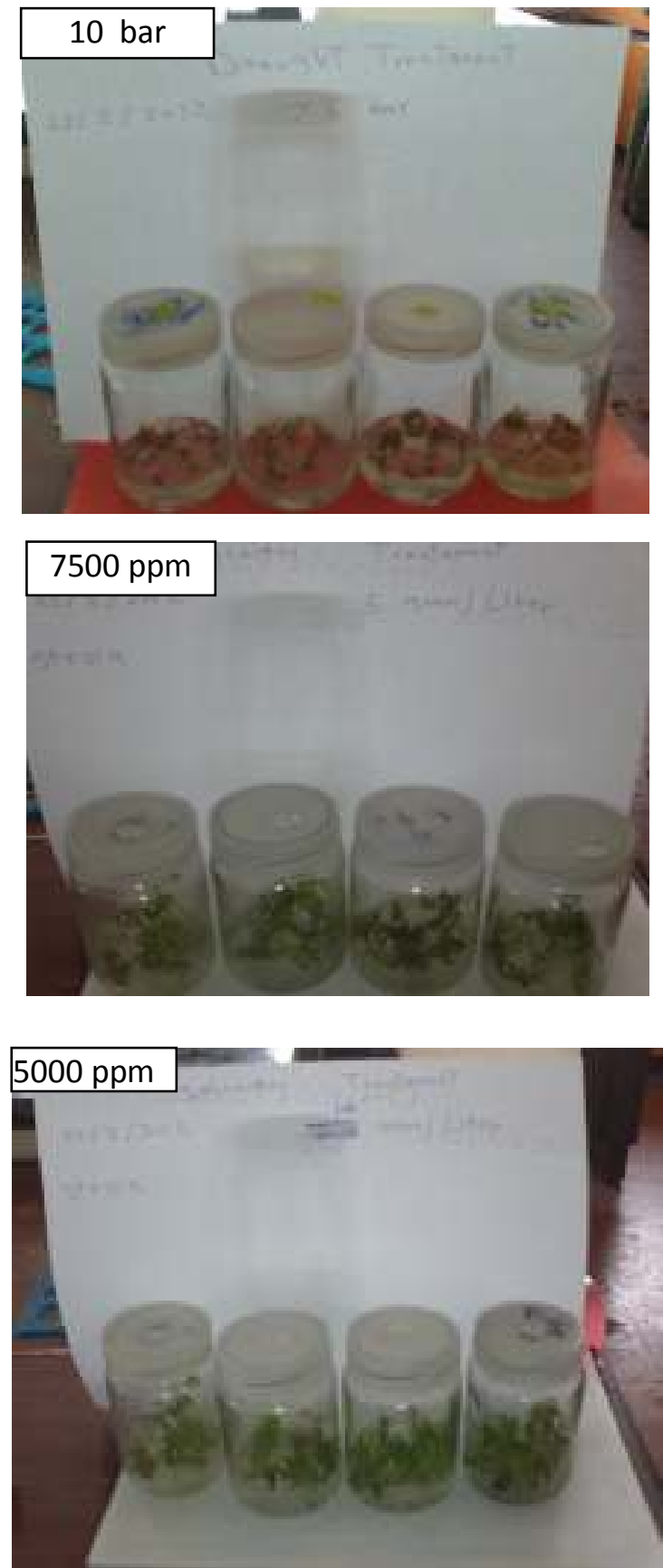

of Flavor and Fragrance. Portland, Oregon: Timber press.

Zidan, I., H. Azaizeh and P. M. Newmann (1990). Does salinity reduce growth in maize root epidermal cell by inhibiting their capacity. Plant Physi., 93: 7-11.
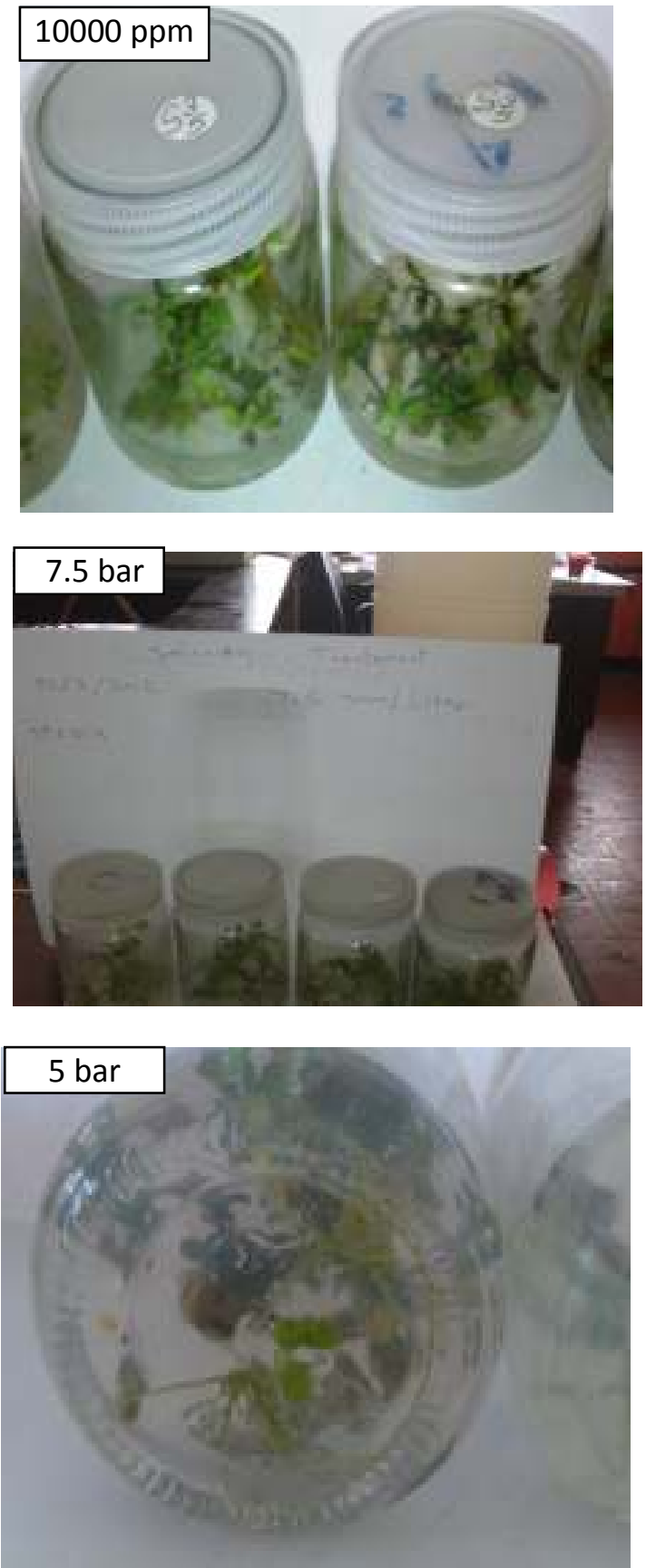

Fig. (1): Effect of drought and salinity stress on Stevia rebaudiana in vitro. 


\section{الملخص العربي}

\section{استجابة الاستيفيا لإجهاد الملوحة والجفاف معمليًا}

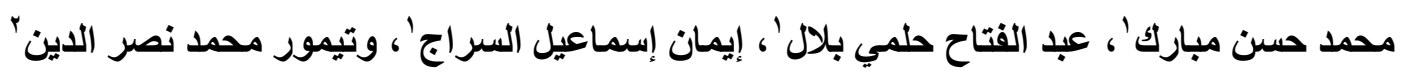

$$
\begin{aligned}
& \text { 1 ـ قسم الإنتاج النباتي، كلية العلوم الزر اعية البيئية بالعريش، جامعة قناة السويس، مصر. }
\end{aligned}
$$

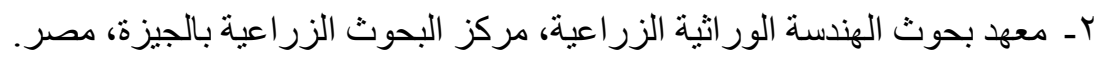

أجريت هذه الدر اسة في معمل زر اعة الأنسجة النباتية في كلية العلوم الزر اعية البيئية العريش، شمال سيناء، جامعة قناة

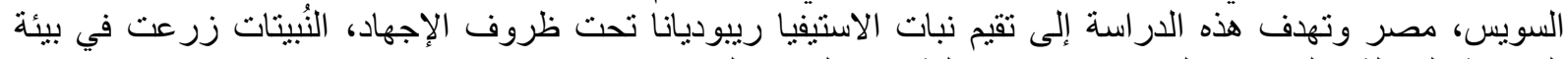

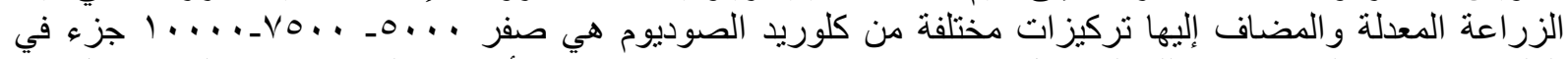

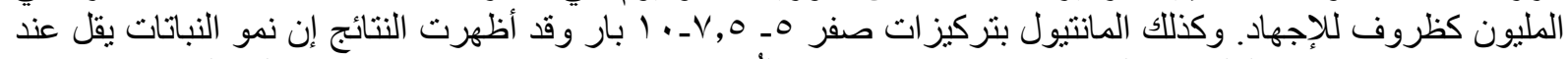

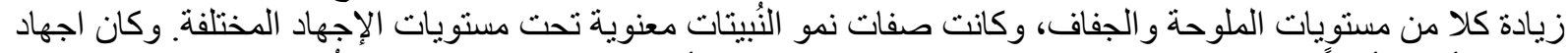

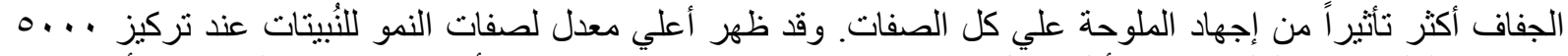

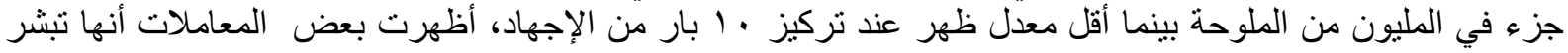

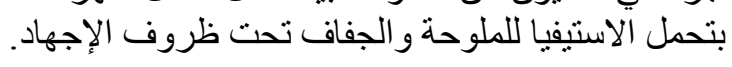
الكلمات الاسترشادية: الاستيفيا، الإجهاد، الملوحة، الجفاف، الإكثار الخضرئاهي. 